\title{
Video NeuroImages: Paraneoplastic spinal myoclonus associated with Caspr 2 antibodies
}

Harrison Hines, MTS, Nick M. Murray, MD, Sarah Ahmad, MD, Safwan Jaradeh, MD, and Carl A. Gold, MD, MS Neurology ${ }^{\circledR}$ 2018;90:660-661. doi:10.1212/WNL.0000000000005265
Correspondence

Harrison Hines

harrison.hines@stanford. edu

Figure EMG tracing from the T9 level of the right rectus abdominus

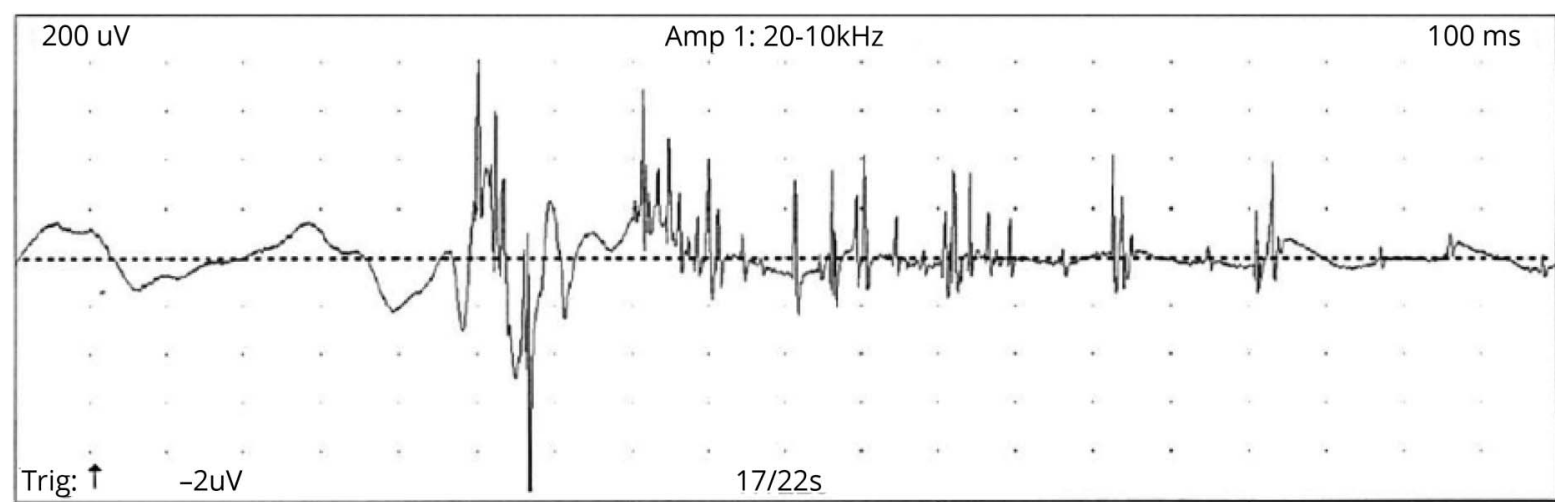

EMG demonstrates an unusual decrescendo firing pattern which, to our knowledge, has not been previously described. Myoclonic bursts varied between 600 milliseconds and 1.8 seconds in duration.

A 42-year-old man with thymoma-associated myasthenia gravis presented with 6 weeks of abnormal leg movements. Examination revealed myoclonus in the legs bilaterally (video, links.lww. com/WNL/A322). Chest CT showed recurrence of metastatic thymoma. MRI spine revealed nonspecific hemosiderin deposition at the T9 level without metastases or vascular malformation. EMG demonstrated right leg and rectus abdominus myoclonus up to T6, most prominently at T9-L1 (figure). Serum anti-contactin-associated protein-like 2 (Caspr2) antibodies were positive. Chemotherapy led to resolution of the myoclonus. Caspr2 antibodies have been associated with limbic encephalitis and neuromyotonia, ${ }^{1,2}$ but our patient showed unusual Caspr2-associated spinal myoclonus.

From Stanford University School of Medicine (H.H.); and Department of Neurology and Neurological Sciences (N.M.M., S.A., S.J., C.A.G.), Stanford University Medical Center, CA.

\section{Author contributions}

Harrison Hines: clinical patient care, acquisition of video data, drafting/revising the manuscript, accepts responsibility for conduct of research and final approval. Nick M. Murray and Sarah Ahmad: clinical patient care, critical revision of the manuscript. Safwan Jaradeh: clinical patient care, analysis of EMG studies. Carl A. Gold: clinical patient care, study supervision, critical revision of the manuscript.

\section{MORE ONLINE}

\section{$\odot$ Video}

links.lww.com/WNL/

A322 


\section{Acknowledgment}

The authors thank Dr. Sarah Yang for help in obtaining and interpreting the EMG results.

\section{Study funding}

No targeted funding reported.

\section{Disclosure}

The authors report no disclosures relevant to the manuscript. Go to Neurology.org/ $\mathrm{N}$ for full disclosures.

\section{References}

1. Van Sonderen A, Ariño H, Petit-pedrol M, et al. The clinical spectrum of Caspr2 antibody-associated disease. Neurology 2016;87:521-528.

2. Song J, Jing S, Quan C, et al. Isaacs syndrome with CASPR2 antibody: a series of three cases. J Clin Neurosci 2017;41:63-66.

\section{Disputes \& Debates: Rapid online correspondence}

The editors encourage comments on recent articles through Disputes \& Debates:

Access an article at Neurology.org/ $N$ and click on "COMMENT" beneath the article header. Responses will be posted within 3 business days.

Before submitting a comment to Disputes \& Debates, remember the following:

- Disputes \& Debates is restricted to comments about studies published in Neurology within the last eight weeks

- Read previously posted comments; redundant comments will not be posted

- Your submission must be 200 words or less and have a maximum of five references; reference one must be the article on which you are commenting

- You can include a maximum of five authors (including yourself)

\section{Register for July Sports Concussion Conference in Indianapolis}

Secure your hotel and take advantage of early registration savings for the 2018 AAN Sports Concussion Conference this July 20 through 22 at the JW Marriott in Indianapolis, IN. The early registration deadline is June 14.

New this year:

- Joint programming with the NCAA including a Networking Reception at the NCAA Hall of Champions and talks focusing on the NCAA-DoD CARE Consortium

- Working Lunch with Experts who will address controversial issues in sports

- A Year in Review featuring the latest updates in concussion research and clinical guidance

- Unique and interactive "What Do I Do Now?" sessions where faculty will share challenging real-life cases and attendees will be invited to weigh in on best practices

Visit AAN.com/view/ConcussionConference 


\section{Neurology}

\section{Video NeuroImages: Paraneoplastic spinal myoclonus associated with Caspr2 antibodies}

Harrison Hines, Nick M. Murray, Sarah Ahmad, et al. Neurology 2018;90;660-661

DOI 10.1212/WNL.0000000000005265

\section{This information is current as of April 2, 2018}

\section{Updated Information \& Services}

References

Citations

Subspecialty Collections

Permissions \& Licensing

Reprints including high resolution figures, can be found at: http://n.neurology.org/content/90/14/660.full

This article cites 2 articles, 1 of which you can access for free at: http://n.neurology.org/content/90/14/660.full\#ref-list-1

This article has been cited by 3 HighWire-hosted articles: http://n.neurology.org/content/90/14/660.full\#\#otherarticles

This article, along with others on similar topics, appears in the following collection(s):

All Spinal Cord

http://n.neurology.org/cgi/collection/all_spinal_cord

EMG

http://n.neurology.org/cgi/collection/emg

Myasthenia

http://n.neurology.org/cgi/collection/myasthenia

Myoclonus

http://n.neurology.org/cgi/collection/myoclonus

Paraneoplastic syndrome

http://n.neurology.org/cgi/collection/paraneoplastic_syndrome

Information about reproducing this article in parts (figures,tables) or in its entirety can be found online at:

http://www.neurology.org/about/about_the_journal\#permissions

Information about ordering reprints can be found online:

http://n.neurology.org/subscribers/advertise

Neurology ${ }^{\circledR}$ is the official journal of the American Academy of Neurology. Published continuously since 1951, it is now a weekly with 48 issues per year. Copyright () 2018 American Academy of Neurology. All rights reserved. Print ISSN: 0028-3878. Online ISSN: 1526-632X.

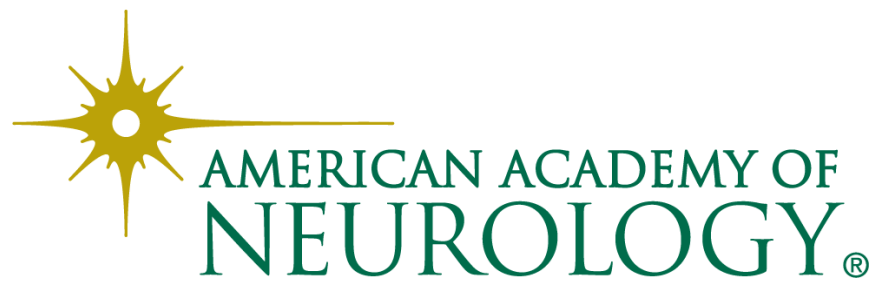

